\title{
Ultrastructural Localization of a Cuticle-degrading Protease Produced by the Entomopathogenic Fungus Metarhizium anisopliae during Penetration of Host (Manduca sexta) Cuticle
}

\author{
By MARK S. GOETTEL,${ }^{*} \dagger$ RAYMOND J. ST LEGER, NANCY W. RIZZO, \\ RICHARD C. STAPLES AND DONALD W. ROBERTS \\ Insect Pathology Resource Center, Boyce Thompson Institute, Tower Road, Cornell University, \\ Ithaca, New York 14853, USA
}

(Received 28 November 1988; revised 14 April 1989; accepted 24 April 1989)

\begin{abstract}
Gold-labelled rabbit antiserum was used to demonstrate that a cuticle-degrading protease $(\operatorname{Pr} 1)$ is produced by Metarhizium anisopliae during penetration of host (Manduca sexta) procuticle. The protease was secreted by infection structures (appressoria) on the cuticle surface and by the penetrant hyphae within the cuticle. Penetration of the procuticle was by a combination of enzymic degradation and mechanical pressure. Initially Prl was confined to the immediate vicinity of the fungal structures; however the enzyme diffused throughout the cuticle during later stages of pathogenesis. When hyphae were labelled during growth in culture under conditions conducive to rapid synthesis of Pr1, gold particles distributed over the fungal cell wall, indicating binding of Prl to hyphae.
\end{abstract}

\section{INTRODUCTION}

The mode of penetration of fungal pathogens into their plant and animal hosts has been a matter of controversy for many years (Charnley, 1984; Van den Ende \& Linskens, 1974). Penetration was considered to be accomplished by mechanical force if the cuticle was depressed inwards at the point of penetration or if cuticular structures appeared to be pushed aside by fungal growth. Lack of such a depression and the appearance of digestion was taken as evidence of enzymic penetration. However, evidence obtained from the plant pathogen Fusarium solani has shown that these two mechanisms are not mutually exclusive; ultrastructural studies with ferritin-conjugated antibody prepared against a plant cell wall degrading enzyme (cutinase) demonstrated the presence of the enzyme during penetration of host cuticle in conjunction with mechanical pressure (Shaykh et al., 1977).

The major structural component of insect cuticle is protein, and recently it was shown that the entomopathogenic fungus Metarhizium anisopliae produces a cuticle-degrading protease with a chymoelastase specificity ( $\mathrm{Prl}$ ) on the surface of host cuticle during the infection process (St Leger et al., $1987 a, b)$. Treating host cuticles with antisera against Pr1 or with specific inhibitors of Prl activity greatly reduced infection (St Leger et al., 1988a).

A previous ultrastructural study of insect cuticle infected with $M$. anisopliae demonstrated apparent zones of histolysis around infection structures (Zacharuk, 1970 b). Using gold-labelled rabbit antisera to $M$. anisopliae chymoelastase $\operatorname{Pr} 1$, we have followed the fate of this enzyme as it is synthesized by infection structures. The results suggest that penetration of the epicuticle is primarily by enzymic degradation while penetration of the procuticle involves both enzymic degradation and the mechanical separation of the lamellae.

† Present address: Crop Sciences Section, Research Station, Research Branch, Agriculture Canada, Lethbridge, Alberta, Canada T1J 4B1. 


\section{METHODS}

Antiserum. Anti-Prl antibody was prepared in rabbits as described by St Leger et al. (1987a).

Organisms and growth. The fungal isolate MEl of Metarhizium anisopliae was cultured on half-strength Sabouraud's dextrose agar for $10 \mathrm{~d}$ at $27^{\circ} \mathrm{C}$. Conidia were harvested by scraping with a rubber policeman. Larvae of Manduca sexta (the tobacco hornworm) were purchased from Carolina Biological Supply Company, Burlington, North Carolina, USA, and reared until early 5th instar.

Tissue inoculation and fixation. Excised Manduca sexta cuticles were prepared and inoculated as described by St Leger et al. $(1987 a)$. In addition, live 4th-instar Manduca sexta larvae were inoculated by dipping in a suspension of conidia $\left(10^{7} \mathrm{ml}^{-1}\right)$. Inoculated cuticles were incubated at $27^{\circ} \mathrm{C}$ for $0,6,24,48$ and $72 \mathrm{~h}$ and fixed at $4{ }^{\circ} \mathrm{C}$ in $3 \%$ (v/v) glutaraldehyde in phosphate buffer $(0.1 \mathrm{M}, \mathrm{pH} 7 \cdot 2)$ for $2 \mathrm{~h}$, washed in buffer, postfixed in $1 \%(\mathrm{w} / \mathrm{v})$ osmium tetroxide (in the same buffer) for $1 \mathrm{~h}$, washed, held in two changes of $70 \%(\mathrm{v} / \mathrm{v})$ ethanol for $1 \mathrm{~h}$ each and then placed into $66 \%(\mathrm{v} / \mathrm{v})$ LR White resin for $1-2 \mathrm{~h}$ at room temperature followed by LR White in a vacuum desiccator overnight, transferred to fresh LR White for $1 \mathrm{~h}$ and allowed to polymerize in a gelatin capsule. Inoculated larvae were incubated at $27^{\circ} \mathrm{C}$ for $48 \mathrm{~h}$, after which $0.5 \mathrm{~cm}$ square cuticles were excised and treated as described above.

Immunocytochemical labelling. Ultrathin sections of LR White embedded tissue were collected on nickel grids, placed in a blocking solution [1\%(w/v) bovine serum albumin (BSA) in phosphate-buffered saline (PBS; $0 \cdot 15 \mathrm{M}$ -

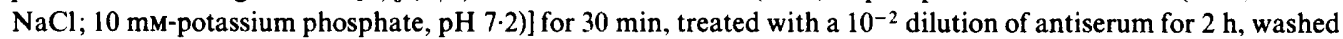
in PBS $/ 0.05 \%$ Tween 20 and then treated with a $10^{-2}$ dilution of Protein A-gold (Sigma; 10 nm diameter) in PBS $/ 0.05 \%$ Tween $20 / 0.2 \%$ BSA for $1.5 \mathrm{~h}$. The sections were then washed in distilled water and stained for contrast in $4 \%(\mathrm{w} / \mathrm{v})$ uranyl acetate in $50 \%(\mathrm{v} / \mathrm{v})$ ethanol for $20 \mathrm{~min}$. Observations were made with a Zeiss EM10a transmission electron microscope.

Controls. These were as follows. (1) Replacement of the antiserum by normal rabbit serum; (2) omission of primary antiserum; (3) non-inoculated cuticle; (4) treatment with Protein A prior to Protein A-gold; (5) fungus grown under conditions of catabolite repression of chymoelastase production (i.e. in Sabouraud's dextrose broth) as compared to growth under conditions inducing chymoelastase production (i.e. locust cuticle) (St Leger et al., 1988b). A Western blot confirmed the mono-specificity of the chymoelastase antiserum used in this study.

\section{RESULTS AND DISCUSSION}

\section{Characterization of the procedure}

Several fixation techniques were tried in order to find an optimum method that both retained the antigenic properties of chymoelastase and preserved the fine structure of tissues. Fixation in glutaraldehyde or glutaraldehyde with picric acid (Newman et al., 1983) resulted in inadequate tissue preservation. In contrast, fixation in glutaraldehyde followed by osmium tetroxide, embedding in Epon-Araldite and pretreating with sodium metaperiodate (Bendayan \& Zollinger, 1983) resulted in lack of antigenicity and increase in non-specific binding. Fixation in $3 \%$ glutaraldehyde followed by $1 \%$ osmium tetroxide and embedding in LR White gave good ultrastructural preservation of the tissues and retention of gold labelling, although diminished as compared with fixation in glutaraldehyde alone (data not presented).

Control sections (see Methods) showed only a very low level of non-specific binding of gold particles, confirming that the anti-Prl serum and protein A-gold complex is a highly specific labelling method for detecting chymoelastase in insect cuticle (data not presented).

\section{Enzyme localization in culture}

Few gold particles were detected when the fungus was cultured under conditions which cause catabolite repression of Prl production (St Leger et al., 1988b) (Fig. 1a). In contrast, gold particles were densely distributed on the hyphal cell walls when the fungus was cultured under conditions which enhance Prl production (Fig. 1b). Few gold particles were found in the cytoplasm, indicating that Pr1 is secreted rapidly after synthesis. This is consistent with previous observations using differential centrifugation of fungal extracts and metabolic inhibitors to investigate intracellular levels of enzyme (St Leger et al., 1988b).

\section{Enzyme localization in situ}

Prl was detected at low levels in dormant conidia or conidia containing the large vacuoles typically seen during germination (Zacharuk, 1970a) (Fig. 2). The density of gold particles 

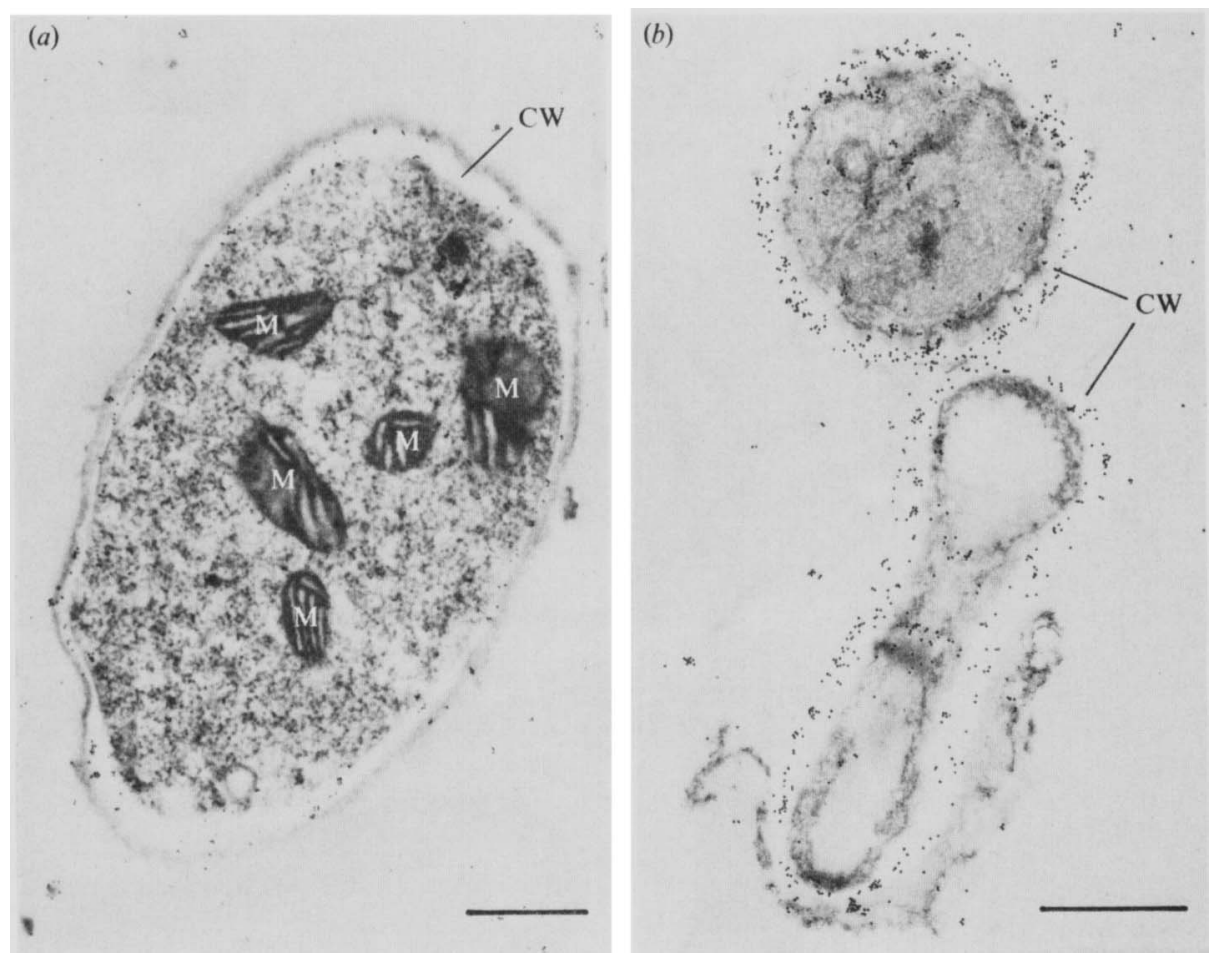

Fig. 1. Protein A-gold immunocytochemical labelling of chymoelastase Pr1 produced by hyphae of Metarhizium anisopliae in broth culture ( $36 \mathrm{~h}$ after inoculation). (a) Hyphae grown in Sabouraud dextrose broth, which results in catabolite repression of Pr 1 . Note that only basal levels of enzyme are produced. (b) Hyphae grown in 1\% chitin broth, which enhances Prl production and secretion. CW, cell wall: M, mitochondrion. Bars, $0.5 \mu \mathrm{m}$.

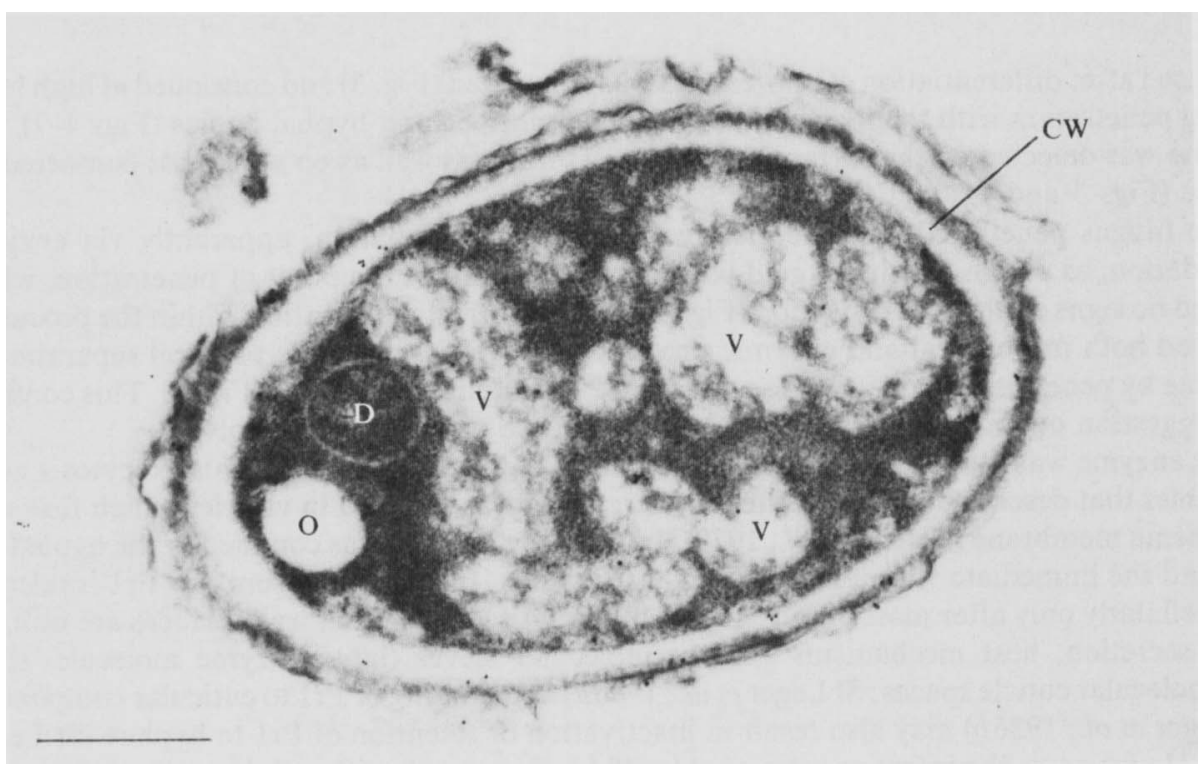

Fig. 2. Protein A-gold labelled chymoelastase Prl produced by a germinating conidium of Metarhizium anisopliae $6 \mathrm{~h}$ after inoculation onto the surface of excised Manduca sexta cuticle. $\mathrm{O}$, oil globule; D, vesiculated dictyosome; $\mathrm{CW}$, cell wall; $\mathrm{V}$, vacuole. Bar, $0.5 \mu \mathrm{m}$. 


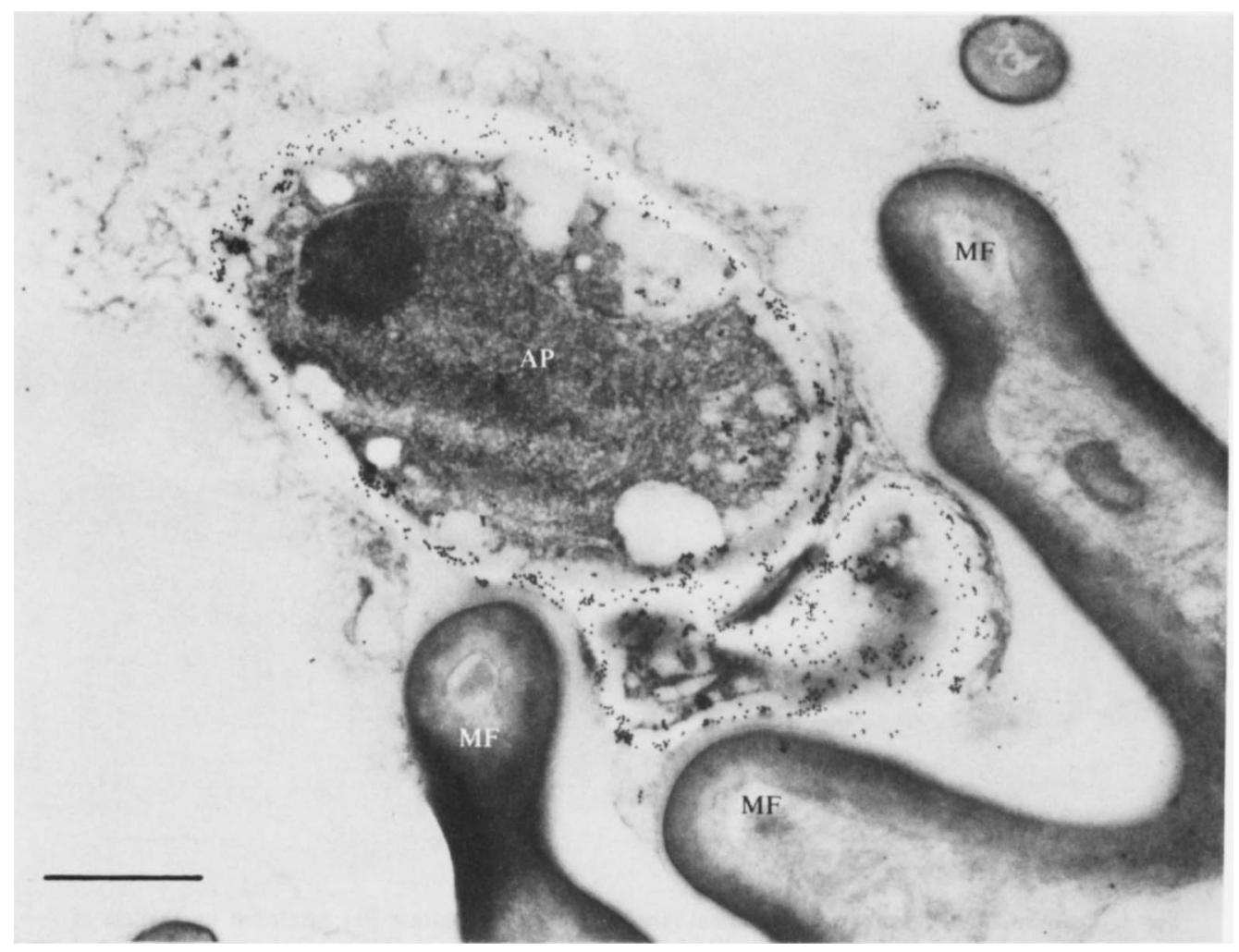

Fig. 3. Protein A-gold labelled chymoelastase Prl produced by a Metarhizium anisopliae appressorium on excised Manduca sexta cuticle ( $24 \mathrm{~h}$ after inoculation). AP, appressorium; MF, microfold. Bar, $0.5 \mu \mathrm{m}$.

increased after differentiation of appressoria was completed (Fig. 3) and continued at high levels during penetration with the formation of the penetrant peg and hyphal bodies (Figs 4-7). The enzyme was detected on the surface of the appressorium as well as on areas that contacted the cuticle (Figs 3 and 4).

The fungus penetrated the epicuticle within $24 \mathrm{~h}$ of inoculation, apparently via enzymic degradation, as a high density of gold particles was present at the point of penetration, which showed no signs of physical distortion (Fig. $4 a, b$ ). In contrast, penetration within the procuticle involved both mechanical and enzymic processes, as evidenced by the physical separation of lamellae by penetrating hyphae and secretion of Pr1 by fungal structures (Fig. 5). This confirms the suggestion of Zacharuk $(1970 b)$ that both of these processes are involved.

The enzyme was secreted from the cell cytoplasm in 'packets' (Fig. 6). This exocytosis event resembles that described in other systems where enzyme is secreted in vesicles which fuse with the plasma membrane (Pollard et al., 1979). Initially the enzyme was confined to the hyphal cell wall and the immediate vicinity of the fungal structures (Figs 3-6). Presumably Pr1 is released extracellularly only after most of the enzyme-binding sites on the cell wall surfaces are utilized. After secretion, host mechanisms such as molecular sieves (large enzyme molecule, small intermolecular cuticle spaces; St Leger et al., 1986a) and binding of $\operatorname{Pr} 1$ to cuticular components (St Leger et al., 1986b) may also result in inactivation or retention of $\operatorname{Pr} 1$ to hyphae (St Leger, 1989). However, as the infection advanced $(\geq 40 \mathrm{~h})$, the enzyme diffused throughout the cuticle (Fig. 7), coincident with breakdown of the cuticle lamellar structure and digestion of the protein moieties. At this stage the host is near death. Melanized cuticle was not as readily digested as unpigmented cuticle (Fig. 4b), as suggested previously by in vitro studies (St Leger et al., 1988c). 

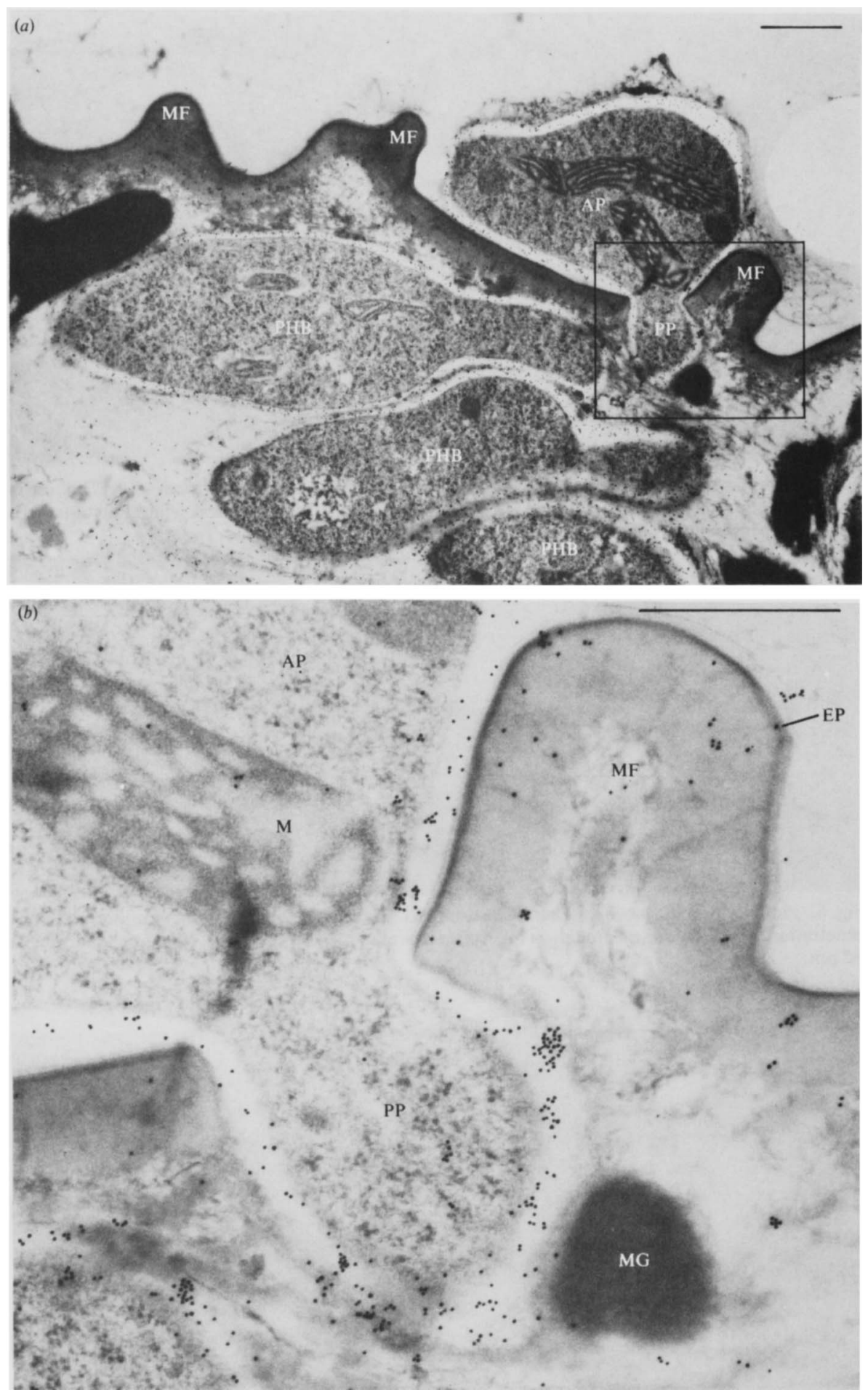

Fig. 4. (a) Protein A-gold labelled chymoelastase Prl produced by Metarhizium anisopliae during penetration of excised Manduca sexta cuticle ( $48 \mathrm{~h}$ after inoculation). AP, appressorium; MF, microfold; PHB, penetrant hyphal body; PP, penetration peg. Bar, $1 \mu \mathrm{m}$. (b) Enlargement of the area boxed in $(a)$. AP, appressorium; EP, epicuticle; M, mitochondrion; MG, melanin granule; PP, penetration peg. Bar, $0.5 \mu \mathrm{m}$. 


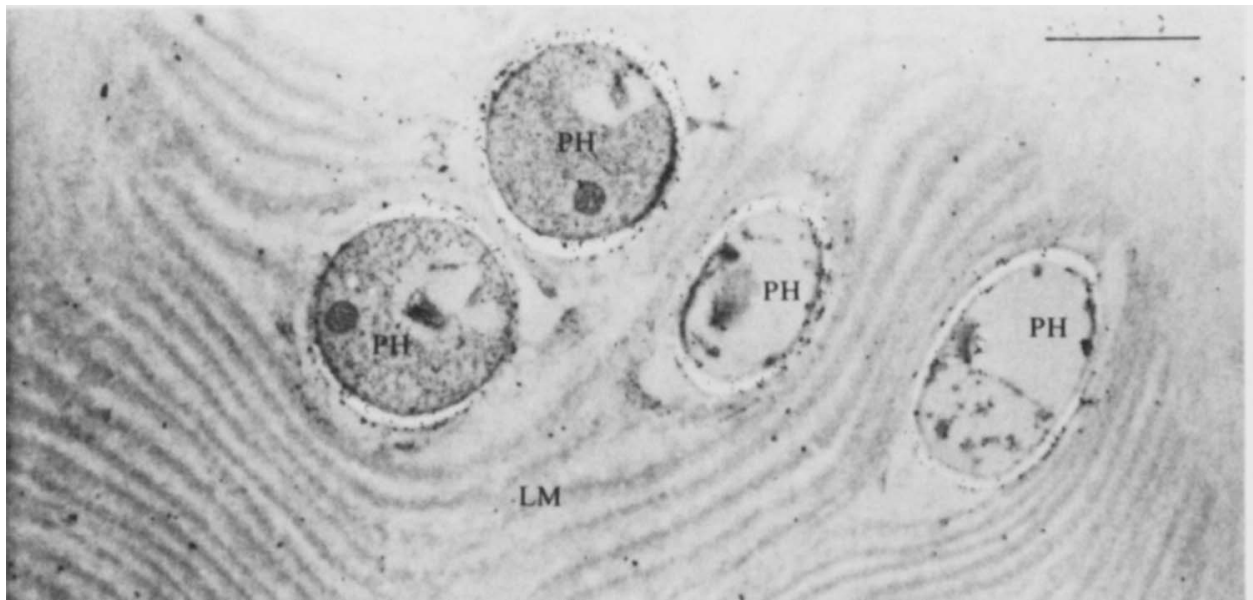

Fig. 5. Protein A-gold labelled chymoelastase Prl secreted by Metarhizium anisopliae during penetration of Manduca sexta procuticle ( $48 \mathrm{~h}$ after inoculation). Note physical separation of lamellae (LM). PH, penetrant hypha. Bar, $1 \mu \mathrm{m}$.

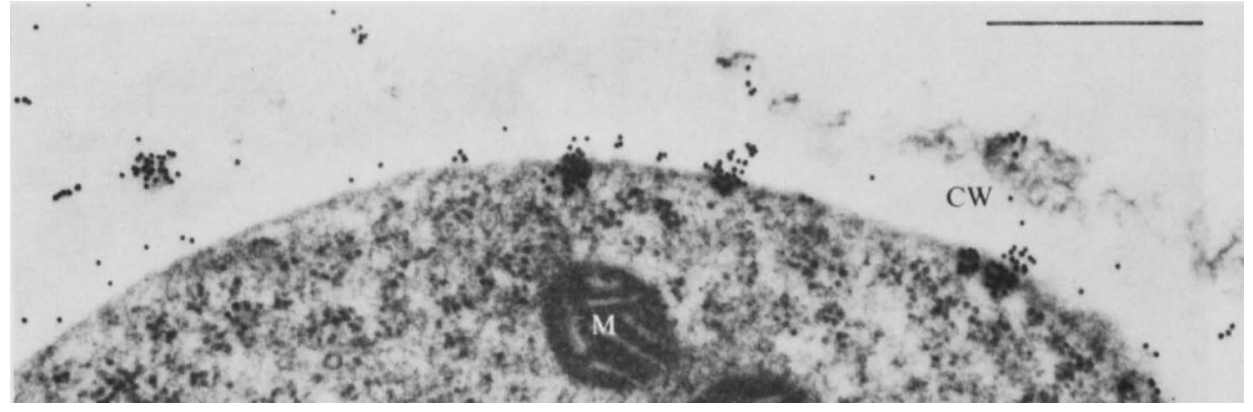

Fig. 6. Protein A-gold labelled chymoelastase Prl secreted by Metarhizium anisopliae during penetration of Manduca sexta procuticle ( $48 \mathrm{~h}$ after inoculation). $\mathrm{CW}$, cell wall; $\mathrm{M}$, mitochondrion. Bar, $0.5 \mu \mathrm{m}$.

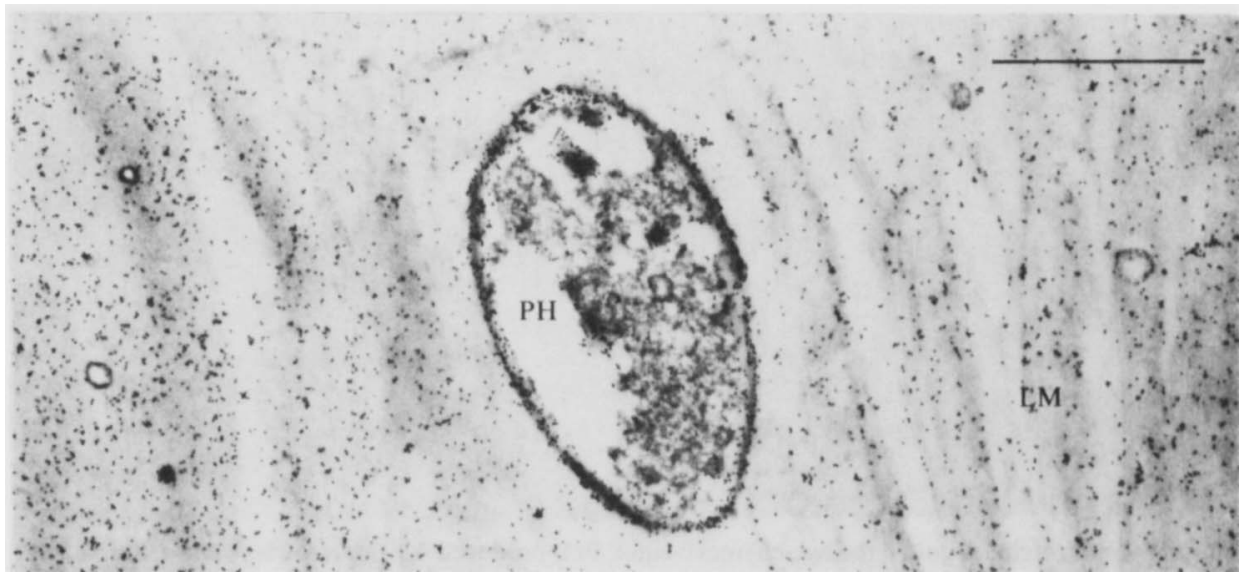

Fig. 7. Protein A-gold labelled chymoelastase Prl diffused throughout the procuticle of a Manduca sexta larva infected by Metarhizium anisopliae ( $72 \mathrm{~h}$ after inoculation). LM, lamellae; PH, penetrant hypha. Bar, $1 \mu \mathrm{m}$. 
Using protein A-gold labelled anti-Prl serum we have demonstrated that $\operatorname{Pr} 1$ is secreted into the cuticle from the infection structures as the fungus penetrates the host cuticle, confirming the important role that this enzyme plays in the invasion process. Our results confirm the work of Zacharuk $(1970 \mathrm{~b})$, indicating that the penetration of insect cuticle involves concurrently both mechanical separation of cuticular laminae and enzymic solubilization of protein polymers. As similar cuticle-degrading proteases are produced by at least five other hyphomycete entomopathogens (St Leger et al., 1987c), these results may have widespread implications in understanding how fungal pathogens initiate disease in insects.

This work was supported by the Natural Sciences and Engineering Research Council of Canada, the USAID Bean/Cowpea Collaborative Research Support Program, the Jesse Smith Noyes Foundation and the Cornell Biotechnology Program, which is sponsored by the New York State Science and Technology Foundation, a consortium of industries and the US Army Research Office.

\section{REFERENCES}

Bendayan, M. \& Zollinger, M. (1983). Ultrastructural localization of antigenic sites on osmium-fixed tissues applying the protein A-gold technique. Journal of Histochemistry and Cytochemistry 31, 101109.

Charnley, A. K. (1984). Physiological aspects of destructive pathogenesis in insects by fungi: a speculative review. In Invertebrate-Microbial Interactions, pp. 229-270. Edited by J. M. Anderson, A. D. M. Raymer \& D. W. H. Walton. London: Cambridge University Press.

Newman, G. R., Jasani, B. \& Williams, E. D. (1983). A simple post-embedding system for the rapid demonstration of tissue antigens under the electron microscope. Journal of Histochemistry and Cytochemistry 15, 543-555.

Pollard, H. B., Pazoles, C. J., Creltz, C. E. \& ZINDER, O. (1979). The chromaffin granule and possible mechanisms of exocytosis. International Review of Cytology 58, 159-197.

Shaykh, M., Soliday, C. \& Kolatrukudy, P. E. (1977). Proof for the production of cutinase by Fusarium solani $\mathrm{f}$. pisi during penetration into its host, Pisum sativum. Plant Physiology 60, 170-172.

ST LEGER, R. J. (1989). The integument as a barrier to microbial infections. In The Physiology of Insect Epidermis. Edited by A. Retnakaran \& K. Binnington. Victoria, Australia: Inkata Press (in the Press).

St leger, R. J., CoOper, R. M. \& Charnley, A. K. (1986a). Restriction of fungal depolymerases by insect host cuticle. In Proceedings International Symposium of Natural Antimicrobial Systems, pp. 316-317. Edited by R. G. Board, A. K. Charnley, R. M. Cooper, G. W. Gould \& M. E. Roberts. Bath: Bath University Press.

St Leger, R. J., Charnley, A. K. \& CoOper, R. M. $(1986 b)$. Cuticle-degrading enzymes of entomopathogenic fungi: mechanisms of interaction between pathogen enzymes and insect cuticle. Journal of Invertebrate Pathology 47, 295-302.

St Leger, R. J., CoOper, R. M. \& Charnley, A. K. $(1987 a)$. Production of cuticle-degrading enzymes by the entomopathogen Metarhizium anisopliae during infection of cuticles from Calliphora vomitoria and Manduca sexta. Journal of General Microbiology 133, 1371-1382.

St Leger, R. J., Charnley, A. K. \& CoOper, R. M. $(1987 \mathrm{~b})$. Characterization of cuticle-degrading proteases produced by the entomopathogen Metarhizium anisopliae. Archives of Biochemistry and Biophysics 253, 221-232.

St Leger, R. J., CoOper, R. M. \& Charnley, A. K. $(1987 c)$. Distribution of chymoelastases and trypsinlike enzymes in five species of entomopathogenic Deuteromycetes. Archives of Biochemistry and Biophysics 258, 123-131.

St Leger, R. J., Durrands, P. K., Charnley, A. K. \& COOPER, R. M. (1988a). Role of extracellular chymoelastase in the virulence of Metarhizium anisopliae for Manduca sexta. Journal of Invertebrate Pathology 52, 285-293.

St Leger, R. J., DurRands, P. K., CoOper, R. M. \& ChARNLEY, A. K. (1988b). Regulation of production of proteolytic enzymes by the entomopathogenic fungus Metarhizium anisopliae. Archives of Microbiology 150, 413-416.

St Leger, R. J., CoOper, R. M. \& Charnley, A. K. (1988c). The effect of melanization of Manduca sexta cuticle on growth and infection by Metarhizium anisopliae. Journal of Invertebrate Pathology 52, 459 470.

VAN DEN ENDE, G. \& LinsKens, H. F. (1974). Cutinolytic enzymes in relation to pathogenesis. Annual Review of Phytopathology 12, 247-258.

ZACHARUK, R. Y. (1970a). Fine structure of Metarhizium anisopliae infecting three species of larval Elateridae (Coleoptera). I. Dormant and germinating conidia. Journal of Invertebrate Pathology 15, 6380.

ZACHARUK, R. Y. $(1970 b)$. Fine structure of the fungus Metarrhizium anisopliae infecting three species of larval Elateridae (Coleoptera). III. Penetration of the host integument. Journal of Invertebrate Pathology 15, 372-396. 